\section{Husbanding resources}

\section{Colin P. Groves}

Evolution of Domesticated Animals.

Edited by I.L. Mason.

Longman: 1984. Pp.452. 135 .

As archaeozoology has evolved into a discipline in its own right, so there has been a surge of interest in the economics of domestic animals and in the possibility of domesticating new species. Until recently there was little in the way of synthesis on the subject, and no general books had appeared since Zeuner's heavily archaeologically orientated $A$ History of Domesticated Animals (Hutchinson, 1963). Now, suddenly, there is a rush to fill the vacuum. Two recent books of note have been Juliet Clutton-Brock's Domesticated Animals from Early Times (Heinemann, 1981), a general book suitable as an undergraduate text, and Helmut Hemmer's Domestikation: Verarmung der Merkwelt (Vieweg, 1983), so far not translated into English but an essential read for anyone interested in the background to and consequences of the domestication process itself.

Now comes this compilation, intended, as the introduction says, as

a single-volume account of the origin and history of domestic animals, species by species, which will not only be a ready source of exact information but will also provide an introduction to the literature.

In other words, it is not a theory-orientated book like Hemmer's, nor a textbook like Clutton-Brock's, but a source book of data and literature.

There are 69 chapters on different species or groups, including some on potential domesticates and some on experiments in progress. The longer chapters are divided into standard headings: introduction (with sections on nomenclature, general biology, and numbers and distribution); wild ancestor; domestication and early history; recent history and present status; and future prospects. The treatment of these various themes is very variable, and reflects the main interests of the authors of the chapters. Bökönyi is an archaeologist; nearly half of his chapter on the horse is taken up by the section "Domestication and Early History". Epstein and Bichard are both specialists in animal husbandry; more than half of their chapter on the pig is "Recent History and Present Status". Many other contributions are similarly weighted; perhaps the most successful and rounded of them are those by co-authors with different specialities (such as the chapter by Novoa, a veterinarian, and Wheeler, an archaeologist, on llama and alpaca), or by single authors who have made one or a group of species their own (the chapter on the dog, by Clutton-Brock; on the reindeer, by Skjenneberg; and the series on domestic fowl, turkey and goose, by Crawford). There is always at least a nod towards all the statutory topics, though in some instances an author may be way out of his depth: Ryder flounders desperately amid the complexities of the taxonomy of wild sheep, and is not always happy with archaeological concepts (it is surprising to see his apparent unquestioning acceptance of high proportions of juveniles as evidence for domestication in an archaeological context, a line of argument which one would have thought long since thrown into disrepute), but as soon as he starts writing about wool, his lifelong speciality, he is clear, authoritative and a joy to read.

The section on general biology is, one would have thought, pivotal to each chapter, but perhaps because it is part of the introduction it is in most instances disappointingly skimmed over. Some of the best accounts of species' biology are, unexpectedly, in the chapters on minor species (Bali cattle, by Rollinson; yak, by Bonnemaire).

My other main criticism of the book is its lack of an overview. Charles Reed does provide an introductory chapter, "The Beginnings of Animal Domestication", but this is of course from an archaeological point of view, and one would have liked to see similar chapters to cover themes such as the biology of domestication; the question of parallel changes in different species as a consequence of domestication; the suitability of different species for domestication; prospects for new domestication; and so on. I may have misunderstood the purpose of the book here, but it seems to me that discussion of such generalities: would have been helpful from both a theoretical and a practical standpoint.

When all is said and done, however, it is a pleasure to read experts expounding the mysteries of their art and the book remains a monumental success. It is a compilation of essential data - the only one there is. It deals with all species that have ever been domesticated, or conceivably ever could be: the African elephant is there, the European bison, the onager (though I personally think this ought not to have been included), the ostrich, the crocodile. We have the latest on the cane-rat domestication project from the University of Ibadan group; hamsters and gerbils; snails and oysters; and a fascinating survey of silkworms. Whatever its defects, the book will stand for years to come as an invaluable reference work. It will deservedly find a place in the libraries of universities, animal husbandry and veterinary institutes, archaeology teams, and even many schools. And thank you, Mr Mason, for doing it; because it needed to be done.

Colin P. Groves is a Senior Lecturer in the Department of Prehistory and Anthropology, Australian National University, Canberra.
ADVERTISEMENT

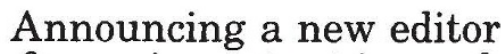
for an important journal

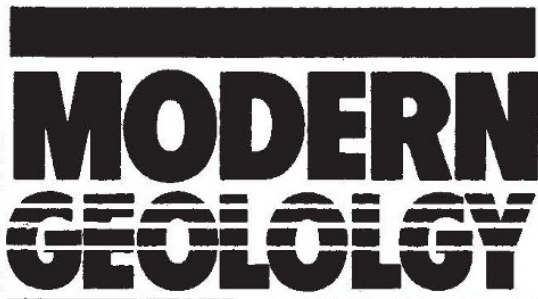

Editor: L. Beverly Halstead, University of Reading, UK

MODERN GEOLOGY reports experimental and theoretical findings at the frontier of geological research. Original papers, reviews and short communications afford comprehensive coverage of important developments in the earth and planetary sciences. The editor aims to preserve a balanced perspective of the physical, chemical and biological spheres and to identify major trends and areas of growth in the field. To complete its far-ranging coverage, the journal offers discussion and comments on previously published contributions, as well as book reviews.

Another attractive feature of the journal is that it includes pertinent colour plates, published at no charge to the contributing author.

\section{Current \& forthcoming papers:}

Hot Dry Rock Geothermal Exploitation in the United Kingdom, A. S. Batchelor. Facies Evolution in the Gulf of Suez Area: Sedimentation History as an Indicator of Rift Initiation and Development, B. W. Sellwood \& R. E. Netherwood. Early Cretaceous Insects from Southern England, E. A. Jarzembowski. Devonian and Carboniferous Tetrapods - A Global Overview, M. J. Boyd. Molecular Organic Geochemistry - A Tool for the Geosciences, G. Eglington.

\section{Subscription information:}

Current volume block: Volumes 8-9

Price per volume of 4 issues: US $\$ 224.00$

$50 \%$ discount to personal subscribers

ISSN: 0026-7775

FREE SAMPLE COPY AVAILABLE

To: Gordon + Breach, c/o STBS,

42 William IV Street,

London WC2N 4DE, UK

Or: Gordon + Breach, c/o STBS,

50 West 23 Street, New York, NY

10010, USA

Yes, please send me a free sample copy of MODERN GEOLOGY

Name

Affiliation

Address

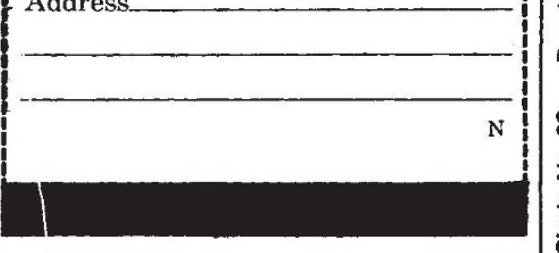

